\title{
THE SUBTERRANEAN ASELLIDS OF MARYLAND: DESCRIPTION OF CAECIDOTEA NORDENI, NEW SPECIES, AND NEW RECORDS OF C. HOLSINGERI AND C. FRANZI (CRUSTACEA: MALACOSTRACA: ISOPODA)
}

\author{
Julian J. LewiS' ${ }^{1}$ AND Thomas E. Bowman²
}

\begin{abstract}
Five species of subterranean asellid are known from Maryland: Caecidotea pricei, C. franzi, C. holsingeri, C. mausi and C. vandeli. Caecidotea nordeni, n. sp. is a subterranean species described from Washington Co., Maryland and assigned to the hobbsi Group. A new locality for C. franzi in Kentucky is presented. This species was previously known from two caves in Maryland and Pennsylvania. The newly discovered population represents a range extension of over $400 \mathrm{~km}$. The male pleopod 2 morphology of specimens from a Maryland population of the subterranean asellid C. holsingeri is compared with populations from three caves in West Virginia. The range of $C$. holsingeri extends from eastern West Virginia and adjacent Virginia to Garrett Co., Maryland.
\end{abstract}

\section{INTRODUCTION}

This paper is part of a long term project to better understand the systematics of subterranean isopods of the family Asellidae that occur in Maryland. This work started as a collaboration between Dan Feller of the Maryland Department of Natural Resources and Thomas E. Bowman of the Smithsonian Institution. Sadly, Dr. Bowman died before any of their work could come to fruition. I took possession of his materials, and after a long hiatus, the project has started to become productive finally.

My first contribution to the Maryland asellid project was the description of Caecidotea mausi Lewis (2009). Four other obligate subterranean species have been recorded from Maryland: C. pricei (Levy 1949), C. franzi (Holsinger and Steeves, 1971), C. holsingeri (Steeves, 1963) and $C$. vandeli (Bresson 1955). Much of what is currently known of the habitat and range of these species was summarized by Lewis (2009). The taxon described below adds a sixth species to Maryland's subterranean asellid fauna.

Another facet of the project was clarification of the ranges of other species already known to occur in Maryland. Few subterranean asellid distribution patterns are well understood due to their cryptic nature and ability to disperse through a variety of groundwater habitats. An example of this is Caecidotea franzi, previously known from Pennsylvania and Maryland, but now discovered in Kentucky and extending their range more than $400 \mathrm{~km}$. Considerably less isolated were the isopods from John Friends Cave, Garrett Co., Maryland, identified by Fleming (1972) as C. holsingeri. There was some suspicion that the Garrett County population represented an undescribed species. To test that theory, Dr. Bowman compared the male pleopod 2 morphology of the Maryland specimens with other $C$. holsingeri populations in West Virginia. That analysis, as well as mapping the collection sites of $C$. holsingeri, led to elucidation of the range of the species.

\section{FAmily Asellidae}

Genus Caecidotea Packard, 1871

CAECIDOTEA NORDENI, NEW SPECIES

Figs. 1-2, 4

Material Examined: MARYLAND: Washington Co., under rocks in stream, $15.2 \mathrm{~km}$ SSE Hancock, 5 Apr 1980, A. Norden, 10\%. The holotype (USNM 337163) is in the collection of the National Museum of Natural History, Smithsonian Institution.

Description of Holotype: Eyeless, unpigmented, $7.8 \mathrm{~mm}$ long, body slender, $5 \times$ as long as wide. Head $1.5 \times$ as wide as long, anterior margin concave, postmandibular lobes slightly produced. Pleotelson slightly longer than wide, sides slightly convex, caudomedial lobe broadly rounded. Mouthparts conforming to diagnosis of genus (Lewis, 2009). Antenna 1 flagellum with 7 articles, distal 3 each bearing a single esthete. Antenna 2 flagellum with 50 articles. Male pereopod 1, propodus about $1.9 \times$ as long as wide, palmar margin with large proximal spine, low medial process; dactyl flexor margin with 5 stout spines.

Male pleopod 1 slightly longer than pleopod 2, protopod $1.2 \times$ as long as wide, with 2 retinaculae; exopod $1.6 \times$ length of protopod, distal margin with 5 elongate plumose setae, lateral margin slightly concave. Pleopod 2, protopod $1.3 \times$ as long as wide, elongate plumose seta and short non-plumose seta on mesodistally, 2 short setae distolaterally; exopod, proximal article with 3 short lateral setae (1 plumose), distal article with 8 elongate, plumose

\footnotetext{
${ }^{1}$ Lewis \& Associates, Cave, Karst \& Groundwater Biological Consulting LLC, 17903 State Road 60, Borden, IN 47106, lewisbioconsult@aol.com

${ }^{2}$ Curator Emeritus (deceased), National Museum of Natural History, Smithsonian Institution
} 


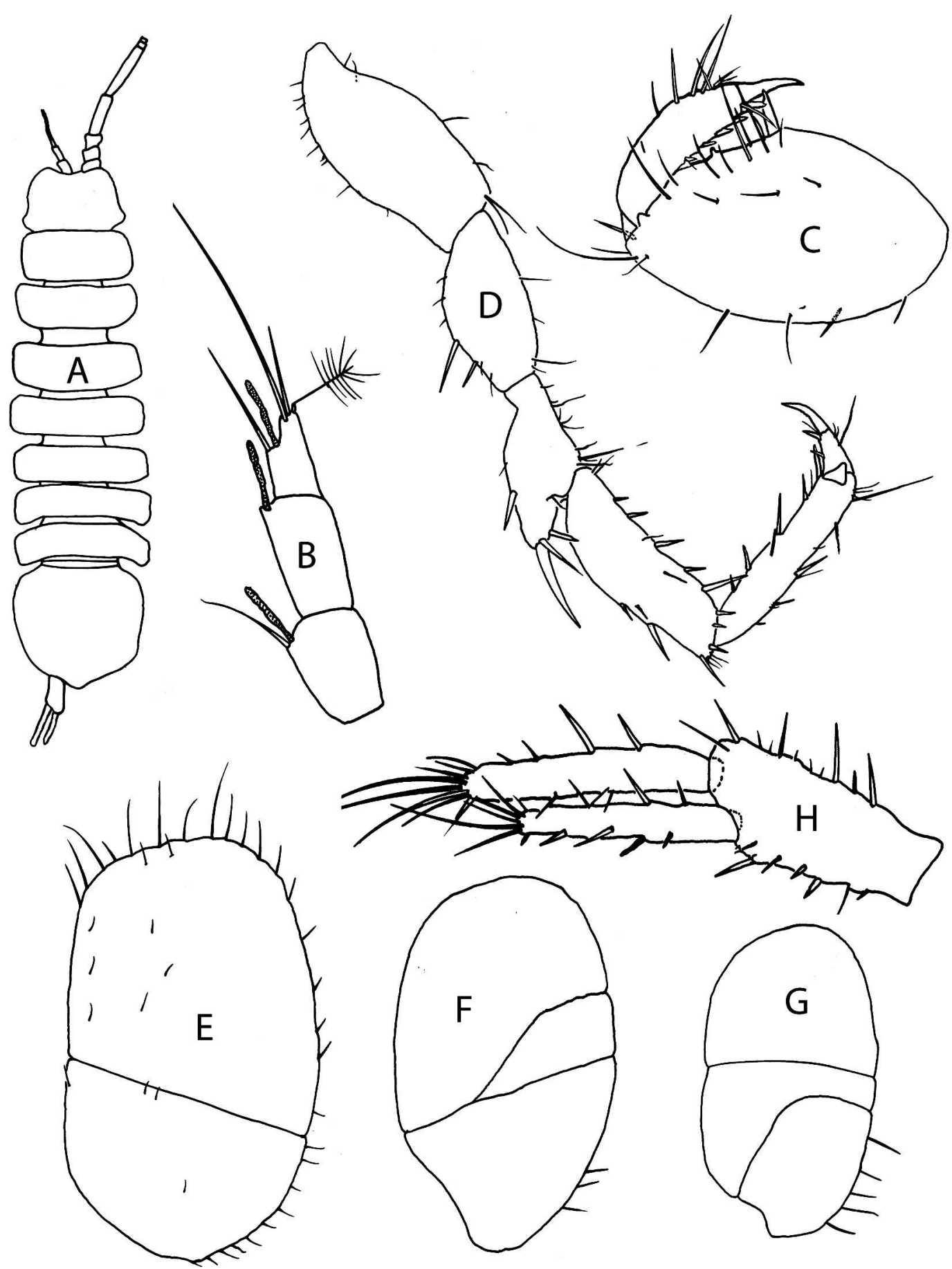

Figure 1. Caecidotea nordeni, new species: (A) habitus, (B) tip articles, antenna 1, (C) gnathopod, distal articles (D) pereopod 4, (E) pleopod 3 exopod, (F) pleopod 4 exopod, (G) pleopod 5 exopod, (H) uropod.

setae along margin. Endopod with well developed basal apophysis; tip with short, slightly conical cannula, small scallops laterally, half obscured by broad mesial process in anterior view, caudal process broadly rounded. Pleopod 3 exopod with 18 plumose setae along apical and lateral margin. Pleopod 4 exopod with sigmoid false suture bifurcating mid-length, 3 setae on proximolateral margin. Pleopod 5 with proximal sigmoid false suture, second false sigmoid suture mid-length, 5 setae on proximolateral margin. Uropods 0.67 length of pleotelson, protopod approximately equal in length to endopod, exopod slightly shorter than endopod.

\section{Relationships}

Other than lacking large processes on the palmar margin of the pereopod 1 propodus, C. nordeni fits the

Journal of Cave and Karst Studies, August 2010 •101 


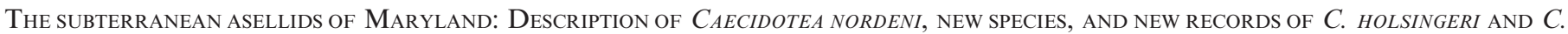
FRANZI (CRUSTACEA: MAlacostraca: IsOPODA)

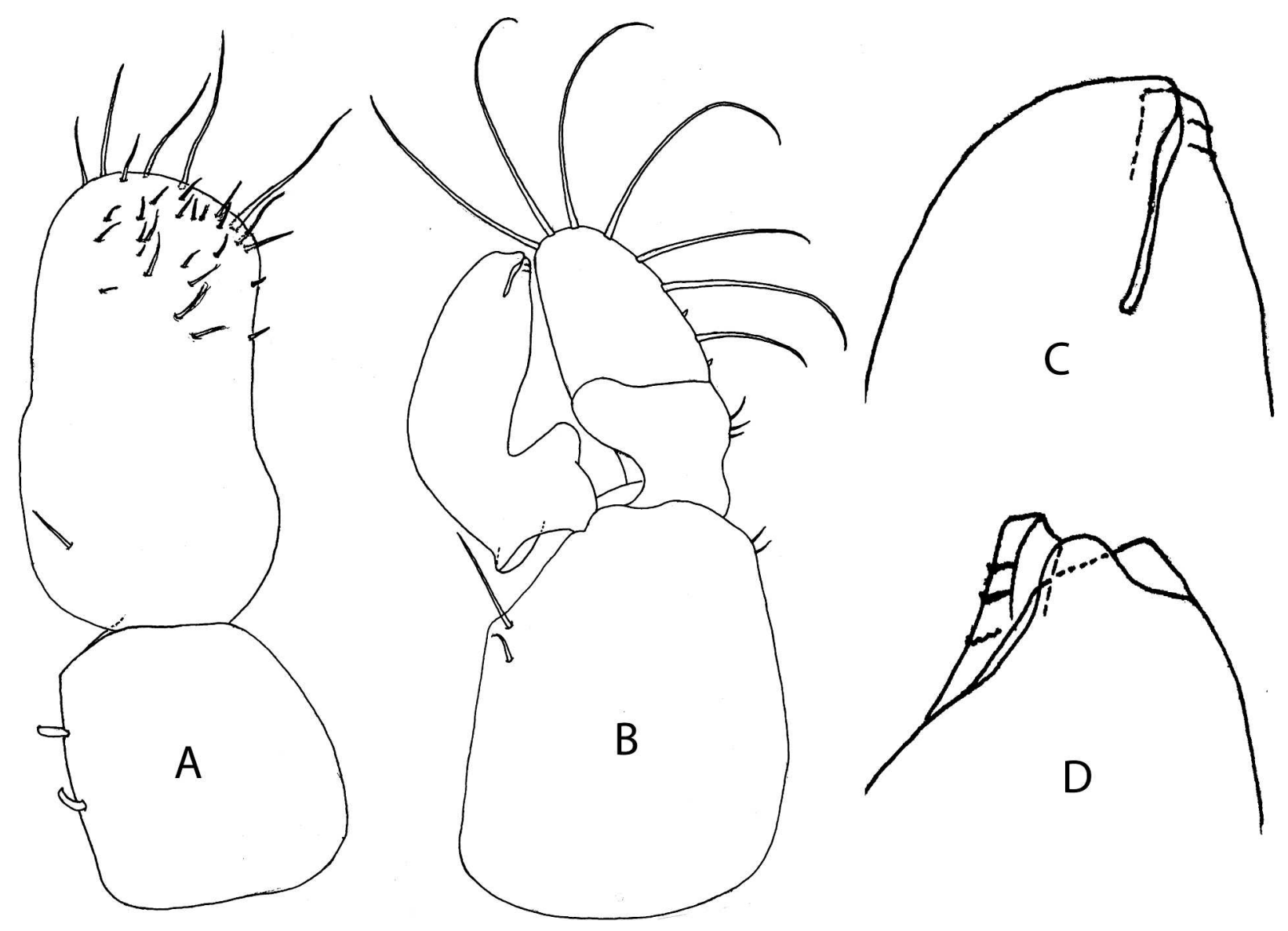

Figure 2. Caecidotea nordeni, new species: (A) pleopod 1, (B) pleopod 2, (C) pleopod 2 endopodite tip, anterior, (D) same, posterior.

diagnosis of the hobbsi Group (Lewis, 1982). In particular, the male first pleopod exopod with concave lateral margin and elongate plumose setae on the apical margin is quite characteristic of the members of this species group. Likewise, the second pleopod endopodite tip, with a short, blunt cannula partially obstructed from view in the anterior aspect is typical of the hobbsi Group. The absence of armature of the pereopod 1 may well be due to the holotype's size, as the processes of the palmar margin usually increase in size with maturity (Bowman and Beckett, 1978). Beyond the placement of C. nordeni in the hobbsi Group, the species does not bear strong resemblance to any of the other described species.

\section{Etymology}

This species is named in honor of the collector, $\mathrm{Mr}$. Arnold Norden. The suggested vernacular name is Norden's groundwater isopod.

\section{Habitat and Range}

This subterranean isopod was found in a surface stream, where it presumably had emerged from a groundwater habitat. Caecidotea nordeni is known only from the type-locality in Washington Co., Maryland.
Franz and Slifer (1971) reported that over half of the 148 caves known in Maryland were located in that county.

CAECidotea FRANZi (Holsinger And Steeves, 1971)

Material Examined: KENTUCKY: Harlan Co., Sawmill Hollow Cave, $1 \mathrm{~km}$ ENE Pine Mountain, James E. Bickford State Nature Preserve, Ellis Laudermilk, 4 Sep 2001, 10’, 1 \%; 24 Sep 2001, 10;, 1 \%; 1 Oct 2001, 20”, 1 o.

This species was previously described from Millers Cave, Centre Co., Pennsylvania and Crabtree Cave, Garrett Co., Maryland. These caves are approximately $185 \mathrm{~km}$ from one another. The appearance of the male gnathopod, pleopod 2 and uropod of the Sawmill Hollow Cave specimens is essentially identical to that illustrated by Holsinger and Steeves (1971). The only significant difference is that the male first pleopod of the Kentucky specimens is not distolaterally produced to the extent shown in the type material. The distal lobes are present in the Sawmill Hollow Cave males and the difference may be a function of curvature of the exopod rather than anatomical.

That the range of $C$. franzi spans $600 \mathrm{~km}$ stretches credence. Certainly other subterranean species (e.g., $C$. stygia, C. kendeighi and C. bicrenata) are found in areas extending as much as $500 \mathrm{~km}$. However, these species are 

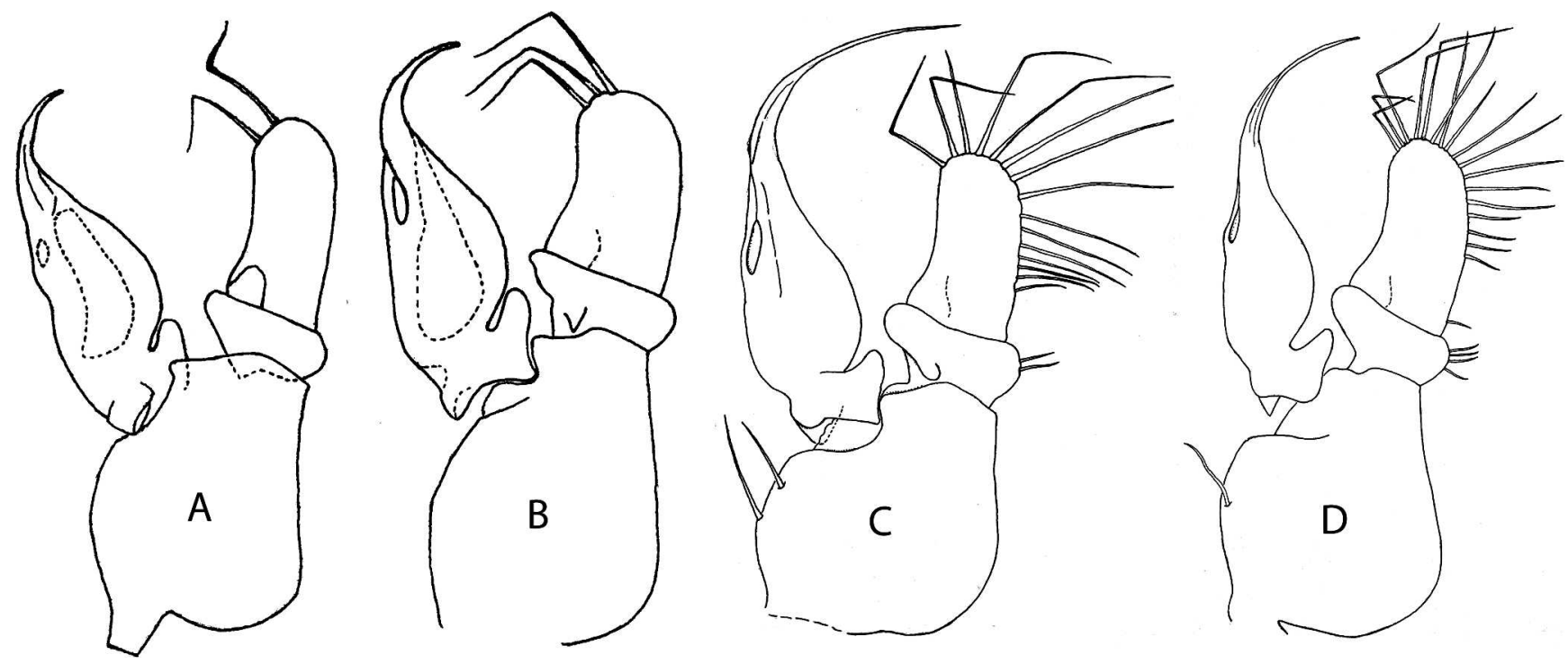

Figure 3. Caecidotea holsingeri (Steeves), variation in male pleopod 2: (A) John Friends Cave, Garrett Co., Maryland, (B) Swecker Stream Cave, Pocahontas Co., WV, (C) Piddling Pit Cave, Pocahontas Co., WV, (D) Organ Cave, Greenbrier Co., WV.

recorded from dozens or even hundreds of collection sites across their respective ranges, while C. franzi is known from few. The anatomy of specimens examined from the Kentucky population is so similar to the description by Holsinger and Steeves (1971) that despite the distance involved, it is considered intraspecific variation until evidence to the contrary is found.

\section{CAEcidotea holsingeri (Steeves, 1963)}

Figs. 3-4

Material examined: MARYLAND: Garrett Co., John Friends Cave, 29 Aug 1966, John R. Holsinger, 10;, 3o (USNM 230649); WEST VIRGINIA, Greenbrier Co., Organ Cave, 13 Jul 1987, David Culver, Janine Gibert 80’o (USNM 235213); Pocahontas Co., Piddling Pit Cave, David Culver, Dan Fong, 23 Nov 1990, 3ơo; Swecker Stream Cave, David Culver, 24 Nov 1990, 30 \%.

The description by Steeves (1963) was adequate for identification of specimens. Steeves (1969) characterized the range as encompassing eastern West Virginia and the western tip of Maryland. Holsinger and Steeves (1971) added the first Virginia locality. Fleming (1972) and Holsinger et. al (1976) listed 27 caves within that range. Lewis (1980) redescribed C. holsingeri, adding details of the morphology and discussing variation. Lewis (2009) added records for Giles and Highland counties, Virginia.

In considering the John Friends Cave population, Thomas Bowman prepared comparative drawings of the male pleopod 2 from three other localities. Other than varying numbers of setae, no significant differences are appreciable. The thread-like cannula terminating the endopodite is fragile and breaks readily, explaining the apparent differences in the length of this structure. A characteristic feature of $C$. holsinger $i$ is the prominent basal apophysis of the male pleopod 2 endopod, which allows the convex lateral edge of the endopod to interlock with the concave exopod (Lewis, 1980, figure 4g).

A plot of the counties in which $C$. holsingeri has been recorded further supports the hypothesis of a single species. This distribution pattern is mirrored by the stygobiont amphipod Stygobromus emarginatus. The range map of the

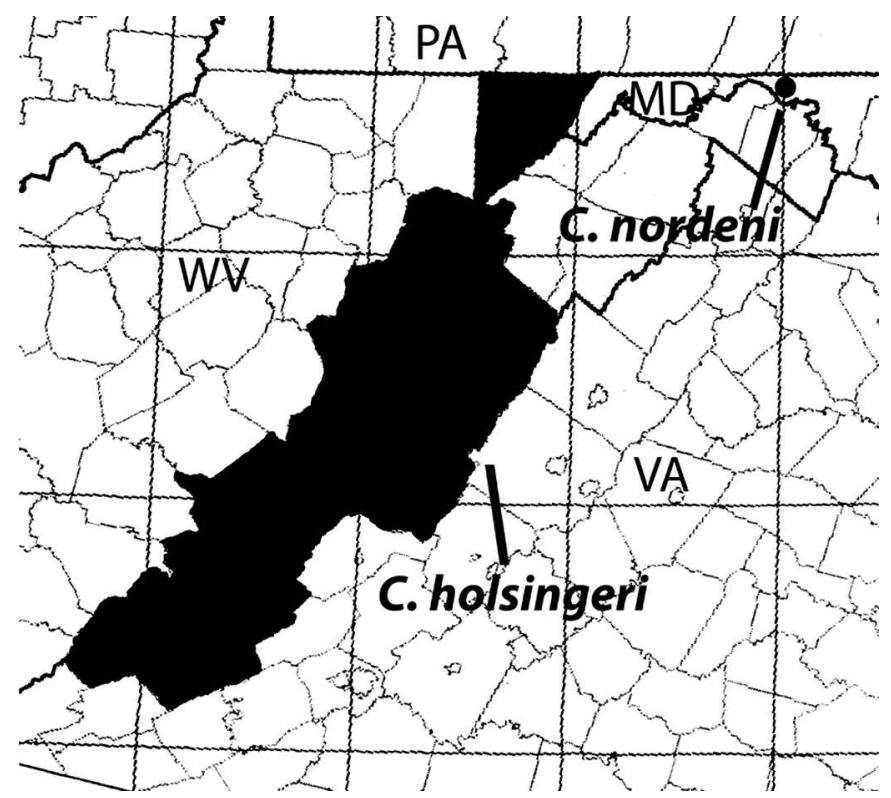

Figure 4. Map of counties of occurrence recorded for Caecidotea holsingeri in Virginia, West Virginia and Maryland. The only known locality of $C$. nordeni, n. sp. in Maryland is indicated by a dot.

Journal of Cave and Karst Studies, August 2010•103 


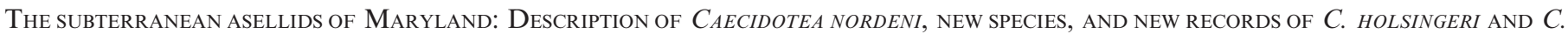
FRANZI (CRUSTACEA: MAlacostracA: IsOPODA)

collection sites for S. emarginatus presented by Holsinger (1978) is nearly identical to the one presented here for $C$. holsingeri. Both species are found primarily in caves developed in the Greenbrier Limestone of Mississippian age suggesting that continuous Paleozoic limestones provide a common dispersal corridor for these species.

\section{ACKNOWLEDGMENTS}

Dr. Bowman's drawings and other materials were provided to me during a visit to the National Museum of Natural History funded by a Visiting Scientist Grant from the Smithsonian Institution. Ms. Marilyn Schotte sponsored that visit, as well as providing specimens from the museum collections. The manuscript was kindly reviewed by Dr. David C. Culver, Mr. Dan Feller, Dr. John R. Holsinger, Mr. Ellis Laudermilk and Ms. Marilyn Schotte. The description of Caecidotea nordeni was funded by the Karst Waters Institute and Cave Conservancy of the Virginias, kindly facilitated by Dr. David C. Culver.

\section{REFERENCES}

Bowman, T.E., and Beckett, D.C., 1978, A redescription of the troglobitic isopod, Caecidotea stygia, from the environs of Cincinnati, Ohio (Crustacea: Isopoda: Asellidae) in Proceedings of the Biological Society of Washington: Washington D.C., v. 91, no. 1, p. 294-302.

Bresson, J., 1955, Aselles de sources et grottes d'Eurasie et d"Amerique du Nord: Archives De Zoologie, Expérimentale et Générale, Notes et Revue, v. 92, p. 45-77.

Fleming, L.E., 1972, The evolution of the eastern North American isopods of the genus Asellus (Crustacea: Asellidae), Part I: International Journal of Speleology, v. 4, p. 221-256.
Franz, R., and Slifer, D., 1971, Caves of Maryland: Baltimore, Md., Maryland Geological Survey, Educational Series No. 3, 120 p.

Holsinger, J.R., 1978, Systematics of the subterranean amphipod genus Stygobromus (Crangonyctidae), Part II: Species of the eastern United States: Smithsonian Contributions to Zoology, v. 266, p. 1-144.

Holsinger, J.R., and Steeves, H.R. III, 1971, A new species of subterranean isopod crustacean (Asellidae) from the central Appalachians, with remarks on the distribution of other isopods of the region in Proceedings of the Biological Society of Washington: Washington, D.C., v. 84, p. 189-200.

Holsinger, J.R., Baroody, R.A., and Culver, D.C., 1976, The invertebrate cave fauna of West Virginia: West Virginia Speleological Survey Bulletin 7, $82 \mathrm{p}$.

Levy, H., 1949, Two new species of cave isopods from Pennsylvania: Notulae Naturae of the Academy of Natural Sciences of Philadelphia, v. 220 , p. $1-6$.

Lewis, J.J., 1980, A comparison of Pseudobaicalasellus and Caecidotea, with a description of Caecidotea bowmani, n. sp. (Crustacea: Isopoda: Asellidae) in Proceedings of the Biological Society of Washington: Washington, D.C., v. 93, no. 2, p. 314-326.

Lewis, J.J., 1982, A diagnosis of the Hobbsi Group, with descriptions of Caecidotea teresae, n. sp., and C. macropropoda Chase and Blair (Crustacea: Isopoda: Asellidae) in Proceedings of the Biological Society of Washington: Washington, D.C., v. 95, p. 338-346.

Lewis, J.J., 2009, Three new species of Caecidotea, with a synopsis of the asellids of Virginia (Crustacea: Isopoda: Asellidae), in Roble, S.M., and Mitchell, J.C., eds., A lifetime of contributions to Myriapodology and the natural history of Virginia: A festschrift in honor of Richard L. Hoffman's $80^{\text {th }}$ birthday, Martinsville, Va., Virginia Museum of Natural History Special Publication no. 16, Martinsville, Va., p. 251-266.

Packard, A.S., 1871, On the crustaceans and insects, in Packard, A.S., and Putnam, F.W., eds., The Mammoth Cave and its inhabitants: American Naturalist, v. 5, no. 12, p. 739-761

Steeves, H.R. III, 1963, Two new troglobitic asellids from West Virginia: American Midland Naturalist, v. 70, p. 461-465.

Steeves, H.R. III, 1969, The origin and affinities of the troglobitic asellids of the southern Appalachians, in Holt, P.C. ed., The distributional history of the biota of the Southern Appalachians, Part I., Invertebrates, Blacksburg, Va., Virginia Polytechnic Institute and State University, Research Division Monograph 1, p. 51-65. 